\title{
Cancer stem cells in head and neck cancer
}

This article was published in the following Dove Press journal:

OncoTargets and Therapy

20 November 2012

Number of times this article has been viewed

\author{
Eugenia Allegra \\ Serena Trapasso \\ Otolaryngology - Head and Neck \\ Surgery, University Magna Graecia \\ of Catanzaro, Catanzaro, Italy
}

Correspondence: Eugenia Allegra Otolaryngology - Head and Neck Surgery, Department of Medical and Surgical Sciences, University Magna Graecia of Catanzaro, Campus Universitario, Località Germaneto, Viale Europa, Catanzaro 88100, Italy $\mathrm{Tel}+39$ 096I 3647130

Fax +39096| 364 7131

Email eualle@unicz.it
Abstract: Cancer stem cells (CSCs), also called "cells that start the tumor," represent in themselves one of the most topical and controversial issues in the field of cancer research. Tumor stem cells are able to self-propagate in vitro (self-renewal), giving rise both to other tumor stem cells and most advanced cells in the line of differentiation (asymmetric division). A final characteristic is tumorigenicity, a fundamental property, which outlines the tumor stem cell as the only cell able to initiate the formation of a tumor when implanted in immune-deficient mice. The hypothesis of a hierarchical organization of tumor cells dates back more than 40 years, but only in 1997, thanks to the work of John Dick and Dominique Bonnet, was there the formal proof of such an organization in acute myeloid leukemia. Following this, many other research groups were able to isolate CSCs, by appropriate selection markers, in various malignancies, such as breast, brain, colon, pancreas, and liver cancers and in melanoma. To date, however, it is not possible to isolate stem cells from all types of neoplasia, particularly in solid tumors. From a therapeutic point of view, the concept of tumor stem cells implies a complete revision of conventional antineoplastic treatment. Conventional cytotoxic agents are designed to target actively proliferating cells. In the majority of cases, this is not sufficient to eliminate the CSCs, which thanks to their reduced proliferative activity and/or the presence of proteins capable of extruding chemotherapeutics from the cell are not targeted. Therefore, the theory of cancer stem cells can pose new paradigms in terms of cancer treatment. Potential approaches, even in the very early experimental stages, relate to the selective inhibition of pathways connected with self-renewal, or more specifically based on the presence of specific surface markers for selective cytotoxic agent vehicles. Finally, some research groups are trying to induce these cells to differentiate, thus making them easier to remove. For all these reasons, we have collected existing literature on head and neck cancer stem cells that correlate the biological characteristics of this subpopulation of cancer cells with the clinical behavior of tumors.

Keywords: head and neck cancer, cancer stem cells, tumor markers

\section{Introduction}

In the last 30 years, progress in the treatment of head and neck cancer has improved the quality of life of patients via the use of innovative surgical and endoscopic techniques that are aimed at the preservation of organ function, mainly in laryngeal tumors. ${ }^{1-3}$ However, the survival of patients with advanced disease has not improved. ${ }^{4,5}$ The main causes of death remain the recurrence of locoregional disease that is unresponsive to conventional treatments and distant metastases. ${ }^{6-8}$ In addition, approximately $10 \%$ of patients in the early stage of disease have recurrence with unfavorable outcome. ${ }^{9,10}$ Recently, the recurrence and lack of response to radiochemotherapy treatments of some tumors has been attributed to a small tumoral 
cell subpopulation termed cancer stem cells (CSCs). This cell subpopulation has been identified in several solid tumors, including head and neck cancer, and it shows certain characteristics that give it the ability to maintain the tumor population, metastasize, and be resistant to chemoradiotherapy. Thus, the CSC hypothesis was proposed as a hierarchical model of tumor origin.

\section{History of the CSC theory}

The idea that cancer can originate from a small population of cells with stem cell properties was proposed about 150 years ago by Francesco Durante in 1874. In "Nesso fisiopatologico tra la struttura dei nei materni e la genesi di alcuni tumori maligni [Nessus pathophysiological between the flaw structure of the mother and the genesis of some malignant tumors]," Durante explains why some aberrant epithelial or connective elements that remained inert for a long time take up highly tumultuous and abnormal activities. ${ }^{11}$ His idea was that "aberrant embryonic stem cells remain in adult tissues and give rise to tumors." His theory was revived and popularized by the German pathologist Cohnheim, who lived during the same period (1839-1884). ${ }^{12}$ The theory was revisited 90 years later by Till and McCulloch, and later by Pierce et al. ${ }^{13,14}$

However, Durante's scientific theory was redefined only in 2001 by Reya et al, as follows: “. . . a strict parallelism can be made between normal stem cells and cancer stem cells: tumors often originate from the transformation of normal stem cells, similar signals can adjust the self-regeneration in normal stem and in tumor cells, and tumor cells may include 'cancer stem cells,' rare cells with an indefinite regenerative potential that leads to tumor genesis." 15

In 1997, Bonnet and Dijk were the first to isolate "cancer stem cells" in samples of acute myeloid leukemia. In their work, they speculated that myeloid leukemia originated by mutation of a normal stem cell according to a "hierarchical

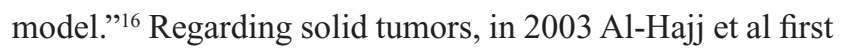
identified and isolated a population of cancer stem cells from breast cancer, showing that only a subset of them, which exhibited expression of the surface markers CD $44^{+} / \mathrm{CD} 24^{- \text {-low }}$, had tumorigenic capacity. ${ }^{17}$

Later, populations of cancer stem cells were identified and isolated in other solid tumors, such as brain, prostate, colorectal, pancreatic, and lung cancers. ${ }^{18-22}$ In head and neck tumors, Prince et al first identified and isolated a cellular subpopulation expressing the surface marker CD44 that exhibited stem-like characteristics and was capable of reproducing when a tumor was implanted in immunosuppressed mice. ${ }^{23}$

\section{Characteristics of CSCs}

The basic characteristics that distinguish CSCs are: (1) promotion of tumorigenesis when they are transplanted into immunosuppressed mice; (2) possession of specific cell-surface markers that are not expressed by noncancer stem cells; (3) tumors that arise from CSCs include both tumorigenic and nontumorigenic cells (heterogeneity); and (4) capacity for self-renewal in seriated transplants over several generations. ${ }^{19,20,24-27}$ These characteristics are derived from the intrinsic properties of CSCs, which reside in their ability to duplicate, differentiate, and control homeostasis.

\section{Origin of CSCs}

Two main hypotheses exist regarding the origin of CSCs: (1) origin from a somatic tissue cell that undergoes genetic mutations, becomes cancerous, and acquires stem characteristics; and (2) derivation from embryonic stem or adult cells as a result of genetic mutations. The first theory does not exclude the second, because the mode of onset may depend on the location of the origin of the tumor.

In squamous cell carcinoma of the oral cavity; for example, the most accepted theory is that the CSCs are derived from the processing of a somatic stem cell. This idea springs from the observation that the time of renewal of epithelial cells of the oral mucosa is about 14-24 days (which is insufficient to accumulate the genetic mutations required for processing). The only accredited hypothesis is that CSCs residing for a long time in the oral mucosa can accumulate sufficient mutations to produce carcinoma of the oral cavity over time. ${ }^{28}$

These new insights have led to a new theory to explain the onset of solid tumors that suggests a hierarchical model, as opposed to the known stochastic model.

\section{The stochastic model}

In 1976, Nowel proposed the stochastic model. According to this theory, tumors originate from a single cell, and tumor progression is derived from a more aggressive subpopulation selected within an original clone over time. ${ }^{29}$ The concept of multistep progression foresaw the stochastic accumulation of numerous genetic mutations underlying the process of neoplastic transformation of solid tumors; it also justified the transition from precancerous to invasive carcinoma as a consequence of the progressive accumulation of genetic mutations, which ultimately determines the origin of a predominant clone and results in a selective advantage over other changed cell populations. ${ }^{7,30-32}$ 


\section{The hierarchical theory}

The hierarchical theory hypothesizes that the tumor originates from embryonic stem cells or somatic cells (present in all tissues) undergoing mutations. These changed stem cells give rise to stem cells that are further altered. Unlike the previous theory, in the hierarchical model, during cell division, one of the two daughter cells retains the ability to replicate, whereas the other loses this capacity and differentiates. Differentiated CSCs represent the majority of the tumor; further mutations that alter the characteristics of the parent cells may intervene during the process of CSC duplication, giving rise to cells that are functionally different. Unlike the stochastic model, the hierarchical model considers that tumorigenicity resides in a small subpopulation of cells composing the tumor that retain the capacity of stemness (Figure 1).

Therefore, a tumor can be compared to an aberrant organ that is maintained in a manner similar to that of normal tissues. This body contains a small proportion of CSCs that feed tumor growth, give it the ability to resist radio- and chemotherapy, and promote local or distant metastasis. The remaining cellular components of the tumor represent the tumor mass formed by aberrantly differentiated cells that have lost the ability to replicate. ${ }^{23}$

During tumor progression, the CSC population can perform several tasks. Thus, the following CSC subpopulations can be distinguished: stationary CSCs, which remain incorporated in the epithelia, are not able to spread, are responsible for resistance to chemo- and radiotherapy, and serve to increase tumor volume; and movable CSCs, which are capable of migrating, are localized at the host-tumor interface, and are responsible for the ability to metastasize locoregionally and/or remotely. These specificities of CSCs give rise to two phenomena: niches and the epithelial-mesenchymal transition (EMT) process.

\section{Niches}

One of the main factors contributing to the maintenance of stem cells is a microenvironment called a niche. ${ }^{33}$ Stem cells are stabilized in niches that are specific anatomical locations

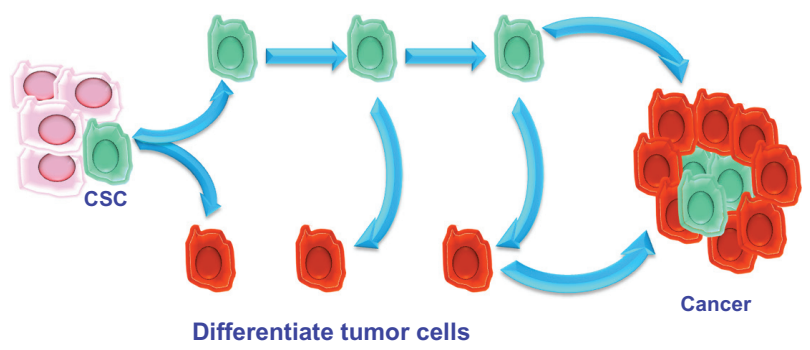

Figure I The hierarchical model. Abbreviation: CSC, cancer stem cell. and help maintain an environment that supports the growth of stem cells. ${ }^{34}$ The maintenance of the microenvironment is mediated by factors that are secreted from stem cells and from the extracellular matrix..$^{35}$ The niche protects CSCs via differentiation and apoptosis and maintains self-regeneration via cell-cell and cell-matrix interactions. Niches also play a fundamental role in resistance to chemo- and radiotherapy and contribute to the genetic instability of CSCs (Figure 2).

\section{Epithelial-mesenchymal transition}

The EMT process is a fundamental stage of embryogenesis. ${ }^{36,37}$ During EMT, epithelial cells break cell-cell and cell-matrix connections and migrate elsewhere. ${ }^{38}$ The aberrant activation of this physiological process is involved in various pathological conditions, such as fibrosis, inflammation, and cancer. During tumor progression, some CSCs undergo EMT and acquire the ability to infiltrate surrounding tissues and metastasize (Figure 3). ${ }^{39}$

It has been shown that non-EMT cells are unable to metastasize without the action of EMT cells, suggesting that the latter are required for invasiveness and metastasis. EMT occurs when the cells are dissociated from each other, lose the expression of epithelial markers and earn the expression of mesenchymal markers, and change their polarization and cytoskeletal structure to establish new cell-matrix interactions. ${ }^{40}$ Once an epithelial cell assumes a mesenchymal appearance and reaches its destination, it can undergo the reverse process of mesenchymal-epithelial transition. ${ }^{38}$

The identification of biomarkers of stem cells with EMT characteristics may facilitate the development of chemotherapeutic agents targeting EMT CSCs. In head and neck tumors, the overexpression of tyrosine kinase receptor B corresponds to an altered expression of the molecular mediators of EMT, including the downregulation of E-cadherin and the upregulation of Twist (a transcription factor that regulates differentiation, adhesion, and proliferation). ${ }^{41}$

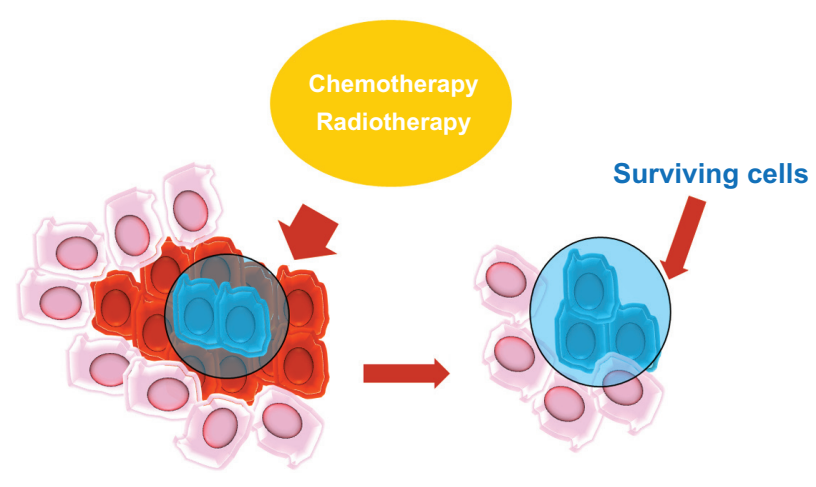

Figure 2 The niches. 


\section{Epithelial-mesenchymal transition}

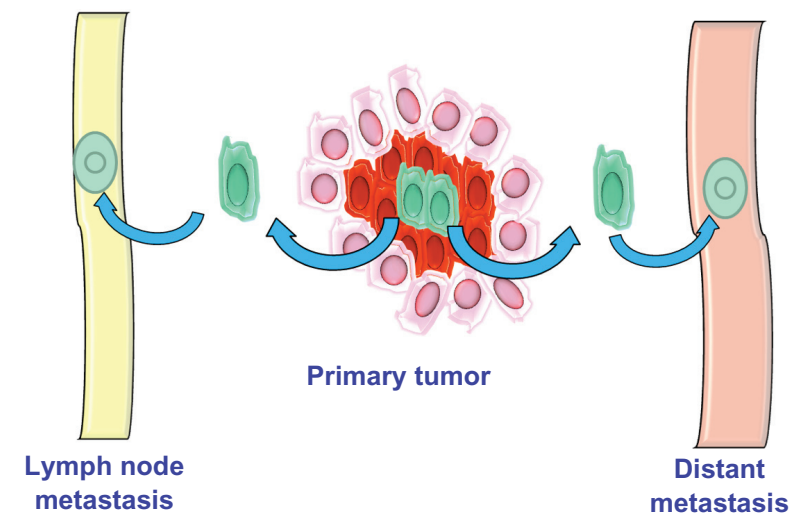

Figure 3 Epithelial-mesenchymal transition.

Chen et al have shown that aldehyde dehydrogenase $1^{+}\left(\mathrm{ALDH}^{+}\right) \mathrm{CSC}$ exhibit upregulated levels of Snail (a transcriptional repressor of genes involved in EMT via E-cadherin) and Twist and show a significant increase in the expression of mesenchymal markers (characteristics of myofibroblasts). ${ }^{42}$

\section{Methods for CSC identification and isolation in solid tumors}

The methods used for the identification and isolation of tumor stem cell populations apply the same techniques used to identify normal stem cells from their differentiated progeny. Cancer stem cells can be identified via surface markers, determination of ALDH activity, ability to efflux vital dyes, and ability to form tumor spheres in vitro.

The subpopulation identified and isolated using these methods is then subjected to tests that prove their tumorigenic ability: quantitative assays of xenografts (which test tumorigenicity) and methods to assess self-renewal in vivo (which test self-renewal capacity).

\section{Surface antigens}

The identification and isolation of CSCs using surface markers is most commonly used for implantation into nonobese diabetic/severe combined immunodeficient mice to grow xenografts. The surface antigens used are the same that are used to identify normal stem cells. The surface antigens involved in solid tumors are CD133, CD44, and CD24.

CD133 is a transmembrane pentaspan glycoprotein localized on the protrusions of the cell membrane; its presence has been reported in various solid tumors, such as brain, prostate, colorectal, and lung cancers. ${ }^{43-46}$ In head and neck tumors, CD133 has only been studied in cell lines. Cells with high expression of CD133 exhibit high clonogenicity, the ability to form spheres, and tumor and tumorigenic capacity in xenograft models compared with cells with low CD133. ${ }^{47-49}$ However, no studies have used $\mathrm{CD} 133^{+}$cells derived from primary head and neck cancer for quantitative assays of xenotransplantation.

CD44 is a surface glycoprotein that is involved in cell migration and adhesion. It is a known receptor of hyaluronic acid and interacts with other "ligands," such as matrix metalloproteases. ${ }^{50,51}$ Prince et al first demonstrated that CD44 expression could be used to isolate a subpopulation with increased tumorigenicity in head and neck tumors. Those authors were able to demonstrate that a small proportion of $\mathrm{CD} 44^{\text {high }}$ cells $(<10 \%)$ that form a tumor can regenerate the tumor when transplanted in the side of immunosuppressed mice, whereas higher concentrations of CD44 ${ }^{\text {low }}$ tumor cells are not able to reform a tumor. ${ }^{23}$ However, the limitation of this study was that in two-thirds of the samples used, it was necessary to pass the cells initially in immunocompromised mice to have a sufficient number of tumor cells to isolate CSCs. This could have altered the expression patterns of native CSCs.

CD24 is a mucin adhesion molecule expressed by pre-B lymphocytes and neutrophils. Functionally, CD24 promotes metastasis, as it has been identified as a ligand of P-selectin, an adhesion receptor found on activated endothelial cells and platelets. Lim and Oh showed that the cytoplasmic expression of CD24 was associated with adenocarcinoma of the colon, stomach, bladder, and ovaries, whereas there is no evidence of this activity in head and neck cancer. ${ }^{52}$

\section{ALDH activity}

ALDH is an intracellular enzyme that is present normally in the liver. Its best-known functions are the retinol conversion to retinoic acid and the oxidation of toxic aldehyde metabolites, such as those formed during the alcohol metabolism and certain chemotherapeutic drugs (eg, cyclophosphamide and cisplatin). ${ }^{53-55}$

Clay et al have shown that a small percentage of ALDH ${ }^{\text {high }}$ tumor cells can produce new head and neck tumors when transplanted into immunosuppressed mice. The majority of isolated cells with $\mathrm{ALDH}^{\text {high }}$ also exhibited high expression of CD44. ${ }^{56}$

\section{Side populations}

Another strategy used to identify highly tumorigenic cellular subpopulations is based on the ability of these cells to efflux a fluorescent dye that binds to DNA. The cell populations isolated using this method are called side populations. 
Using this technique, side populations have been identified in normal tissues and in solid tumors. ${ }^{57}$

The dye used to isolate side populations is Hoechst 33342. Cells that are able to expel the dye, similar to certain chemotherapeutic drugs, express a group of transmembrane transporters, such as multidrug resistance transporter 1 . They are involved in resistance to chemotherapy because of their ability to efflux the drug from the cell and prevent the action of the chemotherapeutic agent. ${ }^{58}$ Cells of head and neck carcinoma were isolated using this method and exhibited increased clonogenicity and tumorigenicity in xenotransplantation. ${ }^{59-60}$

\section{Formation of tumor spheres}

CSCs grown in culture conditions without serum retain an undifferentiated state. The addition of growth factors guides them toward proliferation and formation of cell aggregates that are termed tumor spheres.

In oral cancer, tumor spheres derived from cell lines and from primary tumors show a high tumorigenic capacity in orthotropic xenografts. Okamoto et al reported that CSCs isolated from cell lines from carcinoma of the oral cavity were highly capable of forming spheres and expressed high levels of CD44. ${ }^{61}$ Chiou et al studied two cell lines and primary tumors of the oral cavity and showed that the isolated CSCs had a high capacity to form tumor spheres and expressed high levels of CD133. ${ }^{62}$ However, in a study on 43 primary tumors of the head and neck, Lim et al reported that only $6 \%$ $(3 / 43)$ of the primary tumors formed spheres. ${ }^{63}$

\section{Tumor progression and metastasis}

The tumor stem cell subpopulations identified and isolated using the techniques described above have a demonstrated ability to regenerate a new tumor if replanted in vivo. The next phase of the study of these cells is the determination of the phenotypic characteristics of the isolated populations to understand the mechanisms that underlie the different behaviors of cancer stem cells in terms of ability to metastasize to regional lymph nodes, distant metastasis, and resistance to chemo- and radiotherapy treatments, which are factors that strongly influence survival in patients with head and neck tumors.

\section{Clinical studies}

Existing studies on the clinical significance and applicability of the CSC theory are mainly based on the clinical significance of the tumor expression of stem cell surface markers and on the determination of ALDH expression.
Regarding head and neck tumors, numerous papers have addressed the expression of CD44 and its isoforms. These studies started in the 1990s, before Prince et al demonstrated that the expression of CD44 in head and neck tumors was associated with a tumor subpopulation with stem characteristics. This is because of the known CD44 property as a glycoprotein involved in mechanisms of adhesion and cell migration; hence the hypothesis that the altered expression of this marker could be related to tumor invasiveness. Subsequently, the expression of CD44 in head and neck tumors was linked to subpopulations with characteristics of CSCs. ${ }^{64}$

Studies focused on case studies in different ear, nose, and throat (ENT) locations are clearly not comparable and are contrasting. Some authors argue that the expression of CD44 and its variants shows no significant differences in terms of intensity and percentage of positive cells between normal epithelia and invasive carcinoma, thus CD44 is not a marker of invasiveness, and even reduced CD44 expression appears to correlate with high invasiveness. ${ }^{65-68}$

In contrast, later papers showed that high CD44 expression seems to correlate with a greater ability for lymph-node metastasis, higher recurrence, resistance to radiotherapy, and poor prognosis. ${ }^{69-71}$ In 2009, Wang et al discovered a high correlation between the expression of the CD44v3 isoform and lymph-node metastases and between the expression of the CD44v10 isoform and distant metastases and failure of radiotherapy. ${ }^{70}$

Papers addressing single sites also exhibit discrepancies; however, data obtained on the basis of the different biological behavior of head and neck tumors depending on the site of origin are clearer. Studies on head and neck tumors are limited by the fact that most of them group tumors from various ENT sites with different biological characteristics.

The evidence on squamous cell carcinomas of the oral cavity seems to indicate that low expression of CD44 correlates with a greater capacity of metastasis and recurrence, with negative or no significance on prognosis. ${ }^{72-78}$

Because studies related to the oropharynx are few, the discrepancy in the results reported becomes even more evident. Bloor et al and Carinci et al found no evidence of association between CD44 expression and prognostic significance, whereas Lindquist et al and Kokko et al found a correlation between high expression of CD44 and poor prognosis. ${ }^{77-80}$ However, it must be noted that the number of patients evaluated in the latter two works is greater than that of previous studies.

Among the few clinical trials available for squamous cell carcinomas of the tongue, Fonseca et al reported a relationship 
between high CD44 expression and lymph-node metastasis; in contrast, Mostaan et al, Rodrigo et al, and Masuda et al described a correlation between low CD44 expression and propensity to metastasis and poor prognosis. ${ }^{81-84}$

Studies of squamous cell carcinomas of the hypopharynx and larynx are more numerous, which is probably related to the greater representation of this cancer among head and neck tumors. The high CD44 expression seems to correlate with a poor prognosis more prominently in laryngeal tumors than in the other ENT sites because of the higher metastatic capacity (locoregional and distant) and resistance to chemoradiation of cells with high CD44 expression. ${ }^{77,85-91}$ Moreover, it seems increasingly clear that differences in the propensity to locoregional or distant metastasis and radiotherapy resistance appears to depend on the overexpression of specific variants of CD $44 .^{90-94}$

These results refer to studies performed in the mid-2000s, whereas the previous and even fewer studies reported data correlating a low CD44 expression with poor prognosis and a high risk of recurrence and metastasis. ${ }^{95}$ These differences in reported data may depend on many factors, in addition to the site of origin: differences in the characteristics of the patients selected for these studies (age and tumor, node and metastasis system), different treatments, and different methods used.

Recently, the expression of CD44 was studied in saliva samples from patients with head and neck cancer. Emerging data suggest that CD44 may be a useful diagnostic marker. ${ }^{96-99}$

Only one study is available on the clinical significance of CD133 expression, the work of Lu et al, ${ }^{91}$ in which the authors detected a correlation between the expression of CD44 and CD133 and lymph node metastases in supraglottic tumors; however, those authors believed that the expression of CD133 was not specific to CSCs because of a high percentage of positive cells $(70 \%-85 \%)$ in each slide examined compared with the $5 \%-10 \%$ of cells that were positive for CD 44 .

\section{Studies of ALDH}

Studies on the clinical significance of ALDH expression in head and neck tumors are still very few, which may explain their strongly contrasting results. According to the study of Koukourakis et al, high ALDH expression corresponds to a favorable prognosis, whereas according to $\mathrm{Xu}$ et al, it corresponds to a poor prognosis. ${ }^{71,100}$ However, this variation in the clinical significance of ALDH expression may depend on the expression of the B-cell-specific Moloney murine leukemia virus insertion site 1 (BMI1) protein. BMI controls the cell cycle and the regeneration of stem cells. The downregulation of p16-mediated BMI1 expression promotes the progression of the cell cycle. According to these studies, the suppression of BMI1 in $\mathrm{ALDH}^{+}$tumors appears to increase the response to radiation, whereas BMI1 overexpression in ALDH-positive tumors increases node metastasis. ${ }^{101,102}$

These data seem to agree with the results described in our recent report based on patients with laryngeal cancer, in whom high BMI expression correlated with metastatic capacity and $\mathrm{BMI}^{\text {low }}$ expression in association with absence of p16 expression seemed to select a subset of patients at high risk for lymph-node metastasis. ${ }^{103,104}$

\section{Conclusion}

Clinical studies on CSC characterization are still few and conflicting. Thus, the data derived from them are not sufficiently reliable for clinical application. To establish the clinical significance of the expression of stem cell markers, larger studies are necessary that involve each headquarter of ENT sites; further studies should verify the functional role of these markers via the analysis of their functionality.

CSC-specific markers may be used to identify specific subpopulations that are resistant to therapy and require more aggressive treatment strategies. In addition, a greater understanding of the microenvironmental factors that support niches and the knowledge of the intercellular mediators that underlie the EMT process may lead to the identification of new potential therapeutic targets.

Future fields of application:

- acknowledge time tumors that damage lymph-node metastases

- recognize tumors that exhibit distant metastasis

- identify mechanisms of radioresistance

- identify new molecules that reach niches.

The many questions that remain unanswered should stimulate further research to confirm or refute the data obtained to date. Both assumptions represent an achievement of research.

\section{Disclosure}

The authors report no conflicts of interest in this work.

\section{References}

1. Garozzo A, Allegra E, La Boria A, Lombardo N. Modified supracricoid laryngectomy. Otolaryngol Head Neck Surg. 2010;142:137-139.

2. Allegra E, Lombardo N, La Boria A, et al. Quality of voice evaluation in patients treated by supracricoid laryngectomy and modified supracricoid laryngectomy. Otolaryngol Head Neck Surg. 2011;145:789-795.

3. Allegra E, Franco T, Trapasso S, Aragona T, Domanico R, Garozzo A. Quality of life in patients treated by organ preservation surgery for early laryngeal carcinoma. Open Access Surg. 2012;5:27-32. 
4. Ferlay J, Parkin DM, Steliarova-Foucher E. Estimates of cancer incidence and mortality in Europe in 2008. Eur J Cancer. 2010;46: 765-781.

5. Jemal A, Bray F, Center MM, Ferlay J, Ward E, Forman D. Global cancer statistics. CA Cancer J Clin. 2011;61:69-90.

6. Jones AS, Morar P, Phillips DE, Field JK, Husband D, Helliwell TR. Second primary tumors in patients with head and neck squamous cell carcinoma. Cancer. 1995;75:1343-1353.

7. Allegra E, Baudi F, La Boria A, Fagiani F, Garozzo A, Costanzo FS. Multiple head and neck tumours and their genetic relationship. Acta Otorhinolaryngol Ital. 2009;29:237-241.

8. Leemans CR, Tiwari R, Nauta JJ, van der Waal I, Snow GB. Recurrence at the primary site in head and neck cancer and the significance of neck lymph node metastases as a prognostic factor. Cancer. 1994;73:187-190.

9. Sjögren EV, Wiggenraad RG, Le Cessie S, Snijder S, Pomp J, Baatenburg de Jong RJ. Outcome of radiotherapy in T1 glottic carcinoma: a population-based study. Eur Arch Otorhinolaryngol. 2009;266:735-744.

10. Franchin G, Minatel E, Gobitti C, et al. Radiotherapy for patients with early-stage glottic carcinoma: univariate and multivariate analyses in a group of consecutive, unselected patients. Cancer. 2003;98: 765-772.

11. Durante F. Nesso fisio-patologico tra la struttura dei nei materni e la genesi di alcuni tumori maligni. [Nessus pathophysiological between the flaw structure of the mother and the genesis of some malignant tumors]. Arch Memor Observ Chir Prat. 1874;11:217. Italian.

12. Cohnheim J. Congenitales, quergestreiftes muskelsarkon der nireren. [Congenitales, striated muscle sarkoma of the kidney]. Virchows Arch. 1875;65:64. Italian.

13. Till JE, McCulloch EA. A direct measurement of the radiation sensitivity of normal mouse bone marrow cells. Radiat Res. 1961;14: 213-222.

14. Pierce GM, Dixon FJ, Verney E. Teratocarcinogenic and tissue forming potentials of the cell types comprising neoplastic embryoid bodies. $L a b$ Invest. 1960;9:583-602.

15. Reya T, Morrison SJ, Clarke MF, Weissman IL. Stem cells, cancer, and cancer stem cells. Nature. 2001;414:105-111.

16. Bonnet D, Dick JE. Human acute myeloid leukemia is organized as a hierarchy that originates from a primitive hematopoietic cell. Nat Med. 1997;3:730-737.

17. Al-Hajj M, Wicha MS, Benito-Hernandez A, Morrison SJ, Clarke MF. Prospective identification of tumorigenic breast cancer cells. Proc Natl Acad Sci U S A. 2003;100:3983-3988.

18. Singh SK, Clarke ID, Terasaki M, et al. Identification of a cancer stem cell in human brain tumors. Cancer Res. 2003;63:5821-5828.

19. Collins AT, Berry PA, Hyde C, Stower MJ, Maitland NJ. Prospective identification of tumorigenic prostate cancer stem cells. Cancer Res. 2005;65:10946-10951.

20. Dalerba P, Dylla SJ, Park IK, et al. Phenotypic characterization of human colorectal cancer stem cells. Proc Natl Acad Sci U S A. 2007; 104:10158-10163.

21. Li C, Heidt DG, Dalerba P, et al. Identification of pancreatic cancer stem cells. Cancer Res. 2007;67:1030-1037.

22. Ho MM, Ng AV, Lam S, Hung JY. Side population in human lung cancer cell lines and tumors is enriched with stem-like cancer cells. Cancer Res. 2007;67:4827-4833.

23. Prince ME, Sivanandan R, Kaczorowski A, et al. Identification of a subpopulation of cells with cancer stem cell properties in head and neck squamous cell carcinoma. Proc Natl Acad Sci U S A. 2007;104 973-978.

24. Singh SK, Hawkins C, Clarke ID, et al. Identification of human brain tumour initiating cells. Nature. 2004;432:396-401.

25. Eramo A, Lotti F, Sette G, et al. Identification and expansion of the tumorigenic lung cancer stem cell population. Cell Death Differ. 2008; 15:504-514.

26. Hermann PC, Huber SL, Herrler T, et al. Distinct populations of cancer stem cells determine tumor growth and metastatic activity in human pancreatic cancer. Cell Stem Cell. 2007;1:313-323.
27. Fang D, Nguyen TK, Leishear K, et al. A tumorigenic subpopulation with stem cell properties in melanomas. Cancer Res. 2005;65: 9328-9337.

28. Costea DE, Tsinkalovsky O, Vintermyr OK, Johannessen AC, Mackenzie IC. Cancer stem cells - new and potentially important targets for the therapy of oral squamous cell carcinoma. Oral Dis. 2006;12:443-454.

29. Nowell PC. The clonal evolution of tumor cell populations. Science. 1976;194:23-28

30. Califano J, Westra WH, Meininger G, Corio R, Koch WM, Sidransky D. Genetic progression and clonal relationship of recurrent premalignant head and neck lesions. Clin Cancer Res. 2000;2:347-352.

31. Garozzo A, Cutrona D, Palmeri S, Maiolino L, Puzzo L, Allegra E. The role of p53 tumor suppressor gene as prognostic factor in laryngeal squamous cell carcinoma. Acta Otorhinolaryngol Ital. 1999;19: 342-347. Italian.

32. Allegra E, Garozzo A, Lombardo N, De Clemente M, Carey TE. Mutations and polymorphisms in mitochondrial DNA in head and neck cancer cell lines. Acta Otorhinolaryngol Ital. 2006;26:185-190.

33. Scadden DT. The stem-cell niche as an entity of action. Nature. 2006;441:1075-1079.

34. Li L, Xie T. Stem cell niche: structure and function. Annu Rev Cell Dev Biol. 2005;21:605-631.

35. Scadden DT. The stem-cell niche as an entity of action. Nature. 2006;441:1075-1079.

36. Mani SA, Guo W, Liao MJ, et al. The epithelial-mesenchymal transition generates cells with properties of stem cells. Cell. 2008;133: 704-715.

37. Morel AP, Lièvre M, Thomas C, Hinkal G, Ansieau S, Puisieux A. Generation of breast cancer stem cells through epithelial-mesenchymal transition. PLoS One. 2008;3:e2888.

38. Radisky DC, LaBarge MA. Epithelial--mesenchymal transition and the stem cell phenotype. Cell Stem Cell. 2008;2:511-512.

39. Thiery JP. Epithelial-mesenchymal transitions in tumour progression. Nat Rev Cancer. 2002;2:442-454.

40. Iwatsuki M, Mimori K, Yokobori T, et al. Epithelial-mesenchymal transition in cancer development and its clinical significance. Cancer Sci. 2010;101:293-299.

41. Albers AE, Chen C, Köberle B, et al. Stem cells in squamous head and neck cancer. Crit Rev Oncol Hematol. 2012;81:224-240.

42. Chen C, Wei Y, Hummel M, et al. Evidence for epithelial-mesenchymal transition in cancer stem cells of head and neck squamous cell carcinoma. PLoS One. 2011;6:e16466.

43. Bauer N, Fonseca AV, Florek M, et al. New insights into the cell biology of hematopoietic progenitors by studying prominin-1 (CD133). Cells Tissues Organs. 2008;188:127-138.

44. Shmelkov SV, St Clair R, Lyden D, Rafii S. AC133/CD133/Prominin-1. Int J Biochem Cell Biol. 2005;37:715-719.

45. O'Brien CA, Pollett A, Gallinger S, Dick JE. A human colon cancer cell capable of initiating tumour growth in immunodeficient mice. Nature. 2007;445:106-110.

46. Wu Y, Wu PY. CD133 as a marker for cancer stem cells: progresses and concerns. Stem Cells Dev. 2009;18:1127-1134.

47. Zhang Q, Shi S, Yen Y, Brown J, Ta JQ, Le AD. A subpopulation of CD133+ cancer stem-like cells characterized in human oral squamous cell carcinoma confer resistance to chemotherapy. Cancer Lett. 2010;289:151-160.

48. Wei XD, Zhou L, Cheng L, Tian J, Jiang JJ, Maccallum J. In vivo investigation of CD133 as a putative marker of cancer stem cells in hep-2 cell line. Head Neck. 2009;31:94-101.

49. Zhou L, Wei X, Cheng L, Tian J, Jiang JJ. CD133, one of the markers of cancer stem cells in Hep-2 cell line. Laryngoscope. 2007;117: 455-460.

50. Isacke CM, Yarwood H. The hyaluronan receptor, CD44. Int J Biochem Cell Biol. 2002;34:718-721.

51. Kajita M, Itoh Y, Chiba T, et al. Membrane-type 1 matrix metalloproteinase cleaves CD44 and promotes cell migration. J Cell Biol. 2001;153:893-904. 
52. Lim SC, Oh SH. The role of $\mathrm{CD} 24$ in various human epithelial neoplasias. Pathol Res Pract. 2005;201:479-486.

53. Bosron WF, Lumeng L, Li TK. Genetic polymorphism of enzymes of alcohol metabolism and susceptibility to alcoholic liver disease. $\mathrm{Mol}$ Aspects Med. 1988;10:147-158.

54. Thomasson HR, Edenberg HJ, Crabb DW, et al. Alcohol and aldehyde dehydrogenase genotypes and alcoholism in Chinese men. Am J Hum Genet. 1991;48:677-681.

55. Visus C, Ito D, Amoscato A, et al. Identification of human aldehyde dehydrogenase 1 family member A1 as a novel CD8+ T-cell-defined tumor antigen in squamous cell carcinoma of the head and neck. Cancer Res. 2007;67:10538-10545.

56. Clay MR, Tabor M, Owen JH, et al. Single-marker identification of head and neck squamous cell carcinoma cancer stem cells with aldehyde dehydrogenase. Head Neck. 2010;32:1195-1201.

57. Zhang P, Zhang Y, Mao L, Zhang Z, Chen W. Side population in oral squamous cell carcinoma possesses tumor stem cell phenotypes. Cancer Lett. 2009;277:227-234.

58. Hirschmann-Jax C, Foster AE, Wulf GG, et al. A distinct "side population" of cells with high drug efflux capacity in human tumor cells. Proc Natl Acad Sci U S A. 2004;101:14228-14233.

59. Loebinger MR, Giangreco A, Groot KR, et al. Squamous cell cancers contain a side population of stem-like cells that are made chemosensitive by ABC transporter blockade. Br J Cancer. 2008;98:380-387.

60. Tabor MH, Clay MR, Owen JH, et al. Head and neck cancer stem cells: the side population. Laryngoscope. 2011;121:527-533.

61. Okamoto A, Chikamatsu K, Sakakura K, Hatsushika K, Takahashi G, Masuyama K. Expansion and characterization of cancer stem-like cells in squamous cell carcinoma of the head and neck. Oral Oncol. 2009;45:633-639.

62. Chiou SH, Yu CC, Huang CY, et al. Positive correlations of Oct-4 and Nanog in oral cancer stem-like cells and high-grade oral squamous cell carcinoma. Clin Cancer Res. 2008;14:4085-4095.

63. Lim YC, Oh SY, Cha YY, Kim SH, Jin X, Kim H. Cancer stem cell traits in squamospheres derived from primary head and neck squamous cell carcinomas. Oral Oncol. 2011;47:83-91.

64. Trapasso S, Allegra E. Role of CD44 as a marker of cancer stem cells in head and neck cancer. Biologics. 2012;6:379-383.

65. van Hal NL, van Dongen GA, Stigter-van Walsum M, Snow GB, Brakenhoff RH. Characterization of CD44v6 isoforms in head and neck squamous cell carcinoma. Int J Cancer. 1999;82:837-845.

66. Mack B, Gires O. CD44s and CD44v6 expression in head and neck epithelia. PLoS One. 2008;3:e3360.

67. Herold-Mende C, Seiter S, Born AI, et al. Expression of CD44 splice variants in squamous epithelia and squamous cell carcinomas of the head and neck. J Pathol. 1996;179:66-73.

68. Kanke M, Fujuu M, Kameyama K, et al. Role of CD44 variant exon 6 in invasion of head and neck squamous cell carcinoma. Arch Otolaryngol Head Neck Surg. 2000;126:1217-1223.

69. Joshua B, Kaplan MJ, Doweck I, et al. Frequency of cells expressing CD44, a head and neck cancer stem cell marker: correlation with tumor aggressiveness. Head Neck. 2012;34:42-49.

70. Wang SJ, Wong G, de Heer AM, Xia W, Bourguignon LY. CD44 variant isoforms in head and neck squamous cell carcinoma progression. Laryngoscope. 2009;119:1518-1530.

71. Koukourakis MI, Giatromanolaki A, Tsakmaki V, Danielidis V, Sivridis E. Cancer stem cell phenotype relates to radio-chemotherapy outcome in locally advanced squamous cell head-neck cancer. $\mathrm{Br} J$ Cancer. 2012;106:846-853.

72. Bahar R, Kunishi M, Kayada Y, Yoshiga K. CD44 variant 6 (CD44v6) expression as a progression marker in benign, premalignant and malignant oral epithelial tissues. Int J Oral Maxillofac Surg. 1997;26:443-446.

73. Ue T, Yokozaki H, Kagai K, et al. Reduced expression of the CD44 variant exons in oral squamous cell carcinoma and its relationship to metastasis. J Oral Pathol Med. 1998;27:197-201.
74. Oliveira LR, Oliveira-Costa JP, Araujo IM, et al. Cancer stem cell immunophenotypes in oral squamous cell carcinoma. J Oral Pathol Med. 2011;40:135-142.

75. Stoll C, Baretton G, Soost F, Löhrs U. The influence of CD44 splice variants to the outcome of patients with oral squamous cell carcinoma. Adv Exp Med Biol. 1998;451:51-55.

76. Uwa N, Kataoka TR, Torii I, et al. CD44 expression is related to poor prognosis of hypopharyngeal squamous cell carcinoma. Acta Otolaryngol. 2011;131:323-329.

77. Carinci F, Stabellini G, Calvitti M, et al. CD44 as prognostic factor in oral and oropharyngeal squamous cell carcinoma. J Craniofac Surg. 2002;13:85-89.

78. Kokko LL, Hurme S, Maula SM, et al. Significance of site-specific prognosis of cancer stem cell marker CD44 in head and neck squamouscell carcinoma. Oral Oncol. 2011;47:510-516.

79. Bloor BK, Rajarajan A, Jaafary-Haghighat K, Odell EW. Transcription and expression of CD44 variant exons by oro-pharyngeal squamous cell carcinomas. Int J Oncol. 2002;21:907-913.

80. Lindquist D, Ahrlund-Richter A, Tarján M, Tot T, Dalianis T. Intense CD44 expression is a negative prognostic factor in tonsillar and base of tongue cancer. Anticancer Res. 2012;32:153-161.

81. Fonseca I, Pereira T, Rosa-Santos J, Soares J. Expression of CD44 isoforms in squamous cell carcinoma of the border of the tongue: a correlation with histological grade, pattern of stromal invasion, and cell differentiation. J Surg Oncol. 2001;76:115-120.

82. Mostaan LV, Khorsandi MT, Sharifian SM, et al. Correlation between E-cadherin and CD44 adhesion molecules expression and cervical lymph node metastasis in oral tongue SCC: predictive significance or not. Pathol Res Pract. 2011;207:448-451.

83. Rodrigo JP, Domínguez F, Alvarez C, González MV, Herrero A, Suárez C. Clinicopathologic significance of expression of CD44s and CD44v6 isoforms in squamous cell carcinoma of the supraglottic larynx. $\mathrm{Am} \mathrm{J}$ Clin Pathol. 2002;118:67-72.

84. Masuda M, Kuratomi Y, Shiratsuchi H, Nakashima T, Naonobu K, Komiyama S. Decreased CD44H expression in early-stage tongue carcinoma associates with late nodal metastases following interstitial brachytherapy. Head Neck. 2000;22:662-665.

85. Yüce I, Bayram A, Cağlı S, Canöz O, Bayram S, Güney E. The role of CD44 and matrix metalloproteinase-9 expression in predicting neck metastasis of supraglottic laryngeal carcinoma. Am J Otolaryngol. 2011;32:141-146.

86. Sun B, Zhao S, Zhou C, Yan Q, Wang H. Detection of PD4, CD44, PCNA protein and its clinical significance in human laryngeal carcinoma. Lin Chung Er Bi Yan Hou Tou Jing Wai Ke Za Zhi. 2010;24:817-819. Chinese.

87. Liu B, Kong W, Gong S, Yang C, Wang G, Zhu L. Relationship between the expression of CD44v6 and development, progress, invasion and metastasis of laryngeal carcinoma. J Huazhong Univ Sci Technolog Med Sci. 2005;25:351-353, 364.

88. Zhao S, Sun B, He J, Ye Q, Lin S, Sun A. The expression of CD44 and its significance in human laryngeal carcinoma. Lin Chuang Er Bi Yan Hou Ke Za Zhi. 2003;17:164-166. Chinese.

89. de Jong MC, Pramana J, van der Wal JE, et al. CD44 expression predicts local recurrence after radiotherapy in larynx cancer. Clin Cancer Res. 2010;16:5329-5338.

90. Yang X, Liu M, Han E, Guo H, Yang Z. Expression and implication of CD44 and nm23-H1 proteins in laryngeal carcinoma. Lin Chung Er Bi Yan Hou Tou Jing Wai Ke Za Zhi. 2008;22:119-122. Chinese.

91. Lu S, Tian J, Lv Z, et al. The probable role of tumor stem cells for lymph node metastasis in supraglottic carcinoma. Pathol Oncol Res. 2011;17:33-38.

92. Staibano S, Merolla F, Testa D, et al. OPN/CD44v6 overexpression in laryngeal dysplasia and correlation with clinical outcome. Br J Cancer. 2007;97:1545-1551. 
93. Rodrigo JP, Dominguez F, Alvarez C, Herrero A, Suarez C. Expression of E-cadherin, CD44s, and CD44v6 in laryngeal and pharyngeal carcinomas. Am J Otolaryngol. 2003;24:384-389.

94. Ostwald J, Pracht O, Rhode E, Kramp B. Are the products of CD44 exons v5 and v6 markers for metastasis of laryngeal carcinomas? Laryngorhinootologie. 1997;76:295-299. German.

95. Woinska-Rojecka T, Chodynicki S, Chyczewski L, Rzewnicki I. CD44 glycoprotein as a prognostic factor in laryngeal cancer. Folia Histochem Cytobiol. 2001;39 Suppl 2:150-151.

96. Franzmann EJ, Reategui EP, Pereira LH, et al. Salivary protein and solCD44 levels as a potential screening tool for early detection of head and neck squamous cell carcinoma. Head Neck. 2012;34: 687-695.

97. Franzmann EJ, Reategui EP, Pedroso F, et al. Soluble CD44 is a potential marker for the early detection of head and neck cancer. Cancer Epidemiol Biomarkers Prev. 2007;16:1348-1355.

98. Franzmann EJ, Reategui EP, Carraway KL, Hamilton KL, Weed DT, Goodwin WJ. Salivary soluble CD44: a potential molecular marker for head and neck cancer. Cancer Epidemiol Biomarkers Prev. 2005;14: 735-739.
99. Allegra E, Trapasso S, Sacco A, Aragona T, Belfiore A, Garozzo A. CD44sol salivary levels detected by ELISA as a diagnostic test for laryngeal carcinomas. J Cancer Sci Ther. 2012;4:330-334.

100. Xu J, Müller S, Nannapaneni S, et al. Comparison of quantum dot technology with conventional immunohistochemistry in examining aldehyde dehydrogenase $1 \mathrm{~A} 1$ as a potential biomarker for lymph node metastasis of head and neck cancer. Eur J Cancer. 2012;48:1682-1691.

101. Yu CC, Lo WL, Chen YW, et al. Bmi-1 regulates snail expression and promotes metastasis ability in head and neck squamous cancer-derived ALDH1-positive cells. J Oncol. 2011;2011:1-16.

102. Chen YC, Chang CJ, Hsu HS, et al. Inhibition of tumorigenicity and enhancement of radiochemosensitivity in head and neck squamous cell cancer-derived ALDH1-positive cells by knockdown of Bmi-1. Oral Oncol. 2010;46:158-165.

103. Allegra E, Puzzo L, Zuccalà V, et al. Nuclear BMI-1 expression in laryngeal carcinoma correlates with lymph node pathological status. World J Surg Oncol. 2012;10:206.

104. Allegra E, Caltabiano R, Amorosi A, Vasquez E, Garozzo A, Puzzo L. Expression of BMI1 and p16 in laryngeal squamous cell carcinoma. Head Neck. Epub June 22, 2012.

\section{Publish your work in this journal}

OncoTargets and Therapy is an international, peer-reviewed, open access journal focusing on the pathological basis of all cancers, potential targets for therapy and treatment protocols employed to improve the management of cancer patients. The journal also focuses on the impact of management programs and new therapeutic agents and protocols on

\section{Dovepress}

patient perspectives such as quality of life, adherence and satisfaction. The manuscript management system is completely online and includes a very quick and fair peer-review system, which is all easy to use. Visit http://www.dovepress.com/testimonials.php to read real quotes from published authors. 